\title{
Effect of urea addition on giant reed ensilage and subsequent methane production by
} \section{anaerobic digestion}

\author{
Shan Liu ${ }^{1,2}$, Xumeng Ge ${ }^{1}$, Lo Niee $\mathrm{Liew}^{3}$, Zhe Liu ${ }^{1}$, Yebo $\mathrm{Li}^{1 *}$
}

1. Department of Food, Agricultural and Biological Engineering, The Ohio State University/Ohio Agricultural Research and Development Center, 1680 Madison Ave., Wooster, OH 44691-4096, USA

2. Key Laboratory of Clean Utilization Technology for Renewable Energy in Ministry of Agriculture, College of Engineering, China Agricultural University, 100083 Beijing, PR China

3. Quasar energy group, 5755 Granger Rd., Cleveland, OH, 44131, USA

* Corresponding author. Tel.: +1 330263 3855; fax: +1 3302633670 .

E-mail address: 1i.851@osu.edu (Y. Li).

\section{Abstract}

The effect of urea addition on giant reed ensilage and sequential anaerobic digestion (AD) of the ensiled giant reed was evaluated. The dry matter loss during ensilage (up to 90 days) with or without urea addition was about $1 \%$. Addition of $2 \%$ urea enhanced production of lactic acid by about 4 times, and reduced production of propionic acid by 2-8 times. Besides, urea addition reduced degradation of cellulose and hemicellulose, and increased degradation of lignin in giant reed during ensilage. Ensilage with or without urea addition had no significant effects on the enzymatic digestibility of giant reed, but ensilage with urea addition achieved a cumulative methane yield of $173 \mathrm{~L} / \mathrm{kg}$ VS, which was $18 \%$ higher than that of fresh giant reed. The improved methane yield of giant reed could be attributed to the production of organic acids and ethanol during ensilage.

Keywords: Giant reed; Ensilage; Urea addition; Lactic acid; Anaerobic digestion 


\section{Introduction}

Giant reed (Arundo donax L.) is a C3 perennial rhizomatous grass that is currently widespread in India, China, the USA, Australia, Southern Africa, and the Mediterranean regions

27 (Scordia et al., 2013). Different from typical C3 plants, which are less productive than C4 plants, giant reed has an unusually high photosynthetic capacity (Rossa et al., 1998), and thus achieves a biomass yield even higher than those of typical C4 plants, such as Miscanthus $\times$ giganteus (Corno et al., 2014). As a result, giant reed has been recognized as one of the most promising energy crops for providing biomass feedstocks for the production of fuels and value-added

32 products (Corno et al., 2014). One approach for bioenergy production from giant reed is anaerobic digestion (AD) which is a well-established and widely-used technology for treating biomass and producing methane as energy (Yu and Schanbacher, 2010). AD of giant reed has been reported in a few publications, and is considered to be an effective and reliable method for harnessing energy from giant reed with low greenhouse gas emissions (Di Girolamo et al., 2013; Dragoni et al., 2011; Ragaglini et al., 2014; Yang and Li, 2014).

In order to maintain a viable biofuel supply chain, storage of raw biomass feedstocks is generally required. Ensilage is a well-known technology for wet biomass storage (Darr and Shah, 2012). During the ensilage, lactic acid bacteria (LAB) consume non-structural carbohydrates under anaerobic conditions, and produce organic compounds, such as lactic acid, acetic acid and ethanol. The accumulation of organic acids, mainly lactic acid, reduces the $\mathrm{pH}$ to about 4.0 , thus preventing further degradation of biomass by inhibiting the activity of microorganisms (Zheng et al., 2011). Under favorable conditions, the silage can be stable for a long period, e.g. one year, with organic dry matter (ODM) loss of less than 10\% (Herrmann et al., 2011). Besides being used for preserving wet feedstocks in the livestock industry, ensilage is also considered a 
47 promising biomass storage method for bioenergy production (Darr and Shah, 2012; Herrmann et

48 al., 2011; Neureiter et al., 2005). The ensiled biomass is particularly suitable for production of methane by $\mathrm{AD}$, because the organic acids and ethanol are also intermediates for biogas 50 production in the AD process. Studies on ensilage of various crops, such as maize and grasses for

et al., 2008; Vervaeren et al., 2010; Yahaya et al., 2001). However, published data on ensilage of giant reed for methane production by $\mathrm{AD}$ is scarce.

Urea treatment has been frequently used in ensilage for improved silage quality, e.g. nutritive value and digestibility (Dias-da-Silva and SundstØ1, 1986; Guedes et al., 2006; Mascarenhas-Ferreira et al., 1989; Sarwar and Khan, 2004). Breakdown of urea to ammonia via hydrolysis during 2-3 weeks of ensiling without any urease addition was reported by Ibrahim et al., (1985). In addition, urea treatment also increased lignin degradation during ensilage of hemp and, subsequently, increased its enzymatic digestibility by $46 \%$ (Pakarinen et al., 2011). To date, there have been no reports on urea treatment for ensilage of giant reed.

The objective of this study was to examine the effect of urea addition on giant reed ensilage, and subsequent methane production from ensiled giant reed via AD. Giant reed ensilage experiments with and without urea addition were conducted for different periods of time. Dry matter loss, lignocellulose degradation, and organic acid accumulation during the ensilage processes were examined. Enzymatic hydrolysis and $\mathrm{AD}$ of giant reed with or without urea addition were then carried out, and the effects of ensilage and urea addition on enzymatic digestibility and methane production were studied. Finally, the correlation between the content of organic acids and ethanol in giant reed (fresh and ensiled) and the corresponding methane yields was further evaluated in order to explain the improved methane yield by ensilage. 
2. Methods

72

73

74

75

76

77

78

79

80

81

82

83

84

85

86

87

88

89

90

91

92

\subsection{Feedstock and inoculum}

Giant reed biomass was harvested from the Ohio State University (OSU) research farm in Columbus, OH, USA on October 3, 2014, ground to pass through a $12 \mathrm{~mm}$ sieve using a shredder-chipper (Mighty Mac, Mackissic Inc., Parker Ford, PA, USA), and ensiled on the same day. Effluent from a mesophilic liquid anaerobic digester (KB BioEnergy, Akron, OH, USA) fed with sewage sludge was used as an inoculum for AD. Characteristics of giant reed biomass and the inoculum for AD are presented in Table 1.

\subsection{Ensilage of giant reed}

The processed giant reed biomass was ensilaged with and without urea addition, respectively. For ensilage with urea addition, the giant reed biomass was mixed with $16 \%(\mathrm{w} / \mathrm{v})$ urea to reach a urea content of $2 \%$ (based on dry weight of biomass) and a moisture content of $40.6 \%(\mathrm{w} / \mathrm{w})$. For ensilage without urea addition, the giant reed biomass was mixed with water to reach the same moisture content $(40.6 \%)$. Ensilage was conducted by packing $1 \mathrm{~kg}$ of the mixture (giant reed biomass with additional water and/or urea) into 1-gallon-size zipper bags (Ziploc vacuum Freezer System, SC Johnson Inc., Racine, WI, USA). For each mixture and the control, 12 bags were prepared. The bags were then vacuumed to minimize the presence of oxygen and placed at room temperature $\left(25 \pm 3^{\circ} \mathrm{C}\right)$. Ensilage was run for different periods of time (30, 60, and 90 days). At each time interval including day 0 , three bags were selected randomly from trials with and without urea treatment and the mixture in each of the three bags was taken out and mixed thoroughly. After sampling for composition analysis, the remaining silage samples were stored at $-20^{\circ} \mathrm{C}$ for $\mathrm{AD}$ and determination of enzymatic digestibility. 


\subsection{Determination of enzymatic digestibility}

Enzymatic digestibility of treated and untreated giant reed was determined according to a Laboratory Analytical Procedure (LAP) reported by National Renewable Energy Laboratory (NREL) (Selig et al., 2008). The activity of the cellulase (Cellic CTec 2, Novozymes, Denmark) was measured according to an NREL LAP (Adney and Baker, 2008). Samples (in duplicate) supplemented with cellulase (60 FPU per gram of cellulose) were incubated at $50^{\circ} \mathrm{C}$ with shaking at $180 \mathrm{rpm}$ for 72 hours, and each hydrolysate was filtered through a $0.2 \mu \mathrm{m}$ nylon membrane filter prior to sugar analysis. The enzymatic digestibility was defined as the glucose 101 yield from cellulose by enzymatic hydrolysis, and calculated as follows:

$$
\text { Enzymatic digestibility }(\%)=\frac{M_{\text {glucose }}}{f \times M_{\text {cellulose }}} \times 100
$$

Where $M_{\text {glucose }}$ is the amount of glucose released from cellulose by enzymatic hydrolysis, $M_{\text {cellulose }}$ is the amount of cellulose in the sample (determined by a method described in section $2.5)$, and $f=180 / 162$ is the conversion factor for cellulose to glucose (Zeng et al., 2007).

\subsection{Anaerobic digestion of ensiled giant reed}

AD was set up by mixing fresh or ensiled giant reed, inoculum, and deionized (DI) water to obtain a feedstock to effluent (F/E) ratio of 0.5 (based on volatile solids, VS) and a total solids (TS) content of 5\%. AD with only inoculum was also run as a control. All AD reactors were conducted in triplicate, and incubated at a mesophilic $\left(37 \pm 1^{\circ} \mathrm{C}\right)$ condition for 30 days. A 5-L

111 Tedlar gas bag (CEL Scientific, Santa Fe Springs, CA, USA) was connected to the outlet of each 112 reactor for biogas collection. Biogas volume and composition were determined every 2 to 4 days.

\subsection{Analytical methods}

TS, VS, total Kjeldahl nitrogen $(\mathrm{TKN})$, ammonia nitrogen $\left(\mathrm{NH}_{3}-\mathrm{N}\right)$, and $\mathrm{pH}$ of samples 
116

117

118

119

120

121

122

123

124

125

126

127

128

129

130

131

132

133

134

135

136

137

138

(APHA, 2005). A $5 \mathrm{~g}$ sample was suspended in $50 \mathrm{~mL}$ of DI water prior to $\mathrm{pH}$ measurement.

The carbon to nitrogen $(\mathrm{C} / \mathrm{N})$ ratio was calculated based on total carbon $(\mathrm{TC})$ and total nitrogen (TN) contents which were determined using an elemental analyzer (Elementar Vario Max CNS, Elementar Americas, Mt. Laurel, NJ, USA). Crude protein content was calculated by determining total organic nitrogen (TKN minus $\mathrm{NH}_{3}-\mathrm{N}$ ) and multiplying by a factor of 6.25 (Hattingh et al., 1967).

Cellulose, hemicellulose, and lignin content was analyzed based on an NREL LAP (Sluiter et al., 2008). Briefly, biomass was extracted with DI water and ethanol in series using an automated extraction unit (Dionex ASE 300 extraction system, Thermo Scientific, Sunnyvale, CA, USA) and then the extractive content was determined. Extractive-free biomass was hydrolyzed to release mono-sugars via a two-step acid hydrolysis, and the concentrations of mono-sugars were measured by high performance liquid chromatography (HPLC). The amount of cellulose was calculated from glucose using a conversion factor of 0.90 . The amount of hemicellulose was calculated from the sum of xylose, arabinose, galactose, and mannose, using a conversion factor of 0.90 for C- 6 sugars and 0.88 for C-5 sugars, respectively. Acid-soluble lignin was measured by ultraviolet-visible (UV-vis) spectroscopy (BioMate 3S spectrophotometer, Waltham, MA, USA), and acid-insoluble lignin was determined by gravimetric analysis. The HPLC (Shimadzu LC-20AB, MD, USA) used for sugar analysis was equipped with a Biorad Aminex HPX-87P column and a refractive index detector (RID). Temperatures of the column and detector were maintained at $60^{\circ} \mathrm{C}$ and $55^{\circ} \mathrm{C}$, respectively, and HPLC grade water was used as the mobile phase with a flow rate of $0.3 \mathrm{~mL} / \mathrm{min}$.

In order to determine the content of lactic acid, acetic acid, propionic acid, butyric acid, and ethanol in biomass, a $10 \mathrm{~g}$ sample was suspended in $100 \mathrm{~mL}$ of DI water and incubated at $4{ }^{\circ} \mathrm{C}$ 
139 for $10 \mathrm{~h}$. The suspension was filtered through a $0.2 \mu \mathrm{m}$ nylon membrane filter, and the filtrate 140 was analyzed by a HPLC that was equipped with a Phenomenex Rezex RFQ-Fast Fruit $\mathrm{H}^{+}$ 141 column (Phenomenex Inc., Torrance, CA, USA), a micro- guard cartridge (Catalog No.125-0129, $14230 \times 4.6 \mathrm{~mm}$ ), a RID, and an ultra violet (UV) detector. Temperature of the column and the 143 detector were set at $60^{\circ} \mathrm{C}$ and $55^{\circ} \mathrm{C}$, respectively, and $2.5 \mathrm{mM} \mathrm{H}_{2} \mathrm{SO}_{4}$ was used as the mobile 144 phase with a flow rate of $0.4 \mathrm{ml} / \mathrm{min}$. RID was used to determine concentrations of lactic acid, 145 acetic acid, and propionic acid. Since butyric acid and ethanol were difficult to separate from 146 each other, their concentrations were determined based on the fact that butyric acid has a high 147 UV absorbance at $190 \mathrm{~nm}$, while ethanol does not have a significant absorbance at this 148 wavelength. Briefly, butyric acid concentration was first determined via the UV detector. The 149 RID peak area of butyric acid at this concentration was calculated based on a pre-established 150 calibration curve for butyric acid, and subtracted from the RID peak area for butyric acid/ethanol. 151 The peak area after subtraction was then used to determine the ethanol concentration.

152 Biogas composition (methane and carbon dioxide) was analyzed by a gas chromatograph 153 (Agilent, HP 6890, Wilmington, DE, USA) equipped with a $30 \mathrm{~m} \times 0.53 \mathrm{~mm} \times 10 \mu \mathrm{m} \mathrm{Rt} 囚-$ 154 Alumina Bond/ $\mathrm{KCl}$ deactivation column and a thermal conductivity detector (TCD). Helium gas 155 was used as a carrier gas at a flow rate of $5.2 \mathrm{~mL} / \mathrm{min}$. The column oven was initially set at $40^{\circ} \mathrm{C}$ 156 for 4 minutes and then increased to $60^{\circ} \mathrm{C}$ with an increment of $20^{\circ} \mathrm{C} /$ minute and held at $60^{\circ} \mathrm{C}$ for 1575 minutes. The temperatures of the injector and detector were set at $150^{\circ} \mathrm{C}$ and $200^{\circ} \mathrm{C}$, 158 respectively. Volume of biogas in the Tedlar gas bag was determined by using a diaphragm 159 pump to draw the biogas out from the bag and inject into a drum-type gas meter (Ritter, Bochum, 160 Germany). 


\subsection{Statistical analysis}

Statistical significance was assessed by analysis of variance (ANOVA, $\alpha=0.05$ ) using Minitab (Version 16, Minitab, Inc., State College, PA, USA).

\section{Results and discussion}

\subsection{Effect of urea addition on compositions of ensiled giant reed}

Generally, stable storage was achieved after 30 days of ensilage with or without urea addition (Table 2). During ensilage of giant reed without urea addition, the DM loss was about $1 \%$ in the first 30 days with a significant $(p<0.05)$ decrease in extractive content and $\mathrm{pH}$, while these values remained relatively constant in the following 60 days. The decrease in extractive content was mainly attributed to the degradation of water soluble carbohydrates (WSC), most of which had been degraded in the first 30 days. For mixtures without urea addition, the $\mathrm{NH}_{3}-\mathrm{N}$, TN, and TC contents and the $\mathrm{C} / \mathrm{N}$ ratio were stable throughout the 90 days of ensilage without significant variations $(p>0.05)$ (Table 2). During ensilage of giant reed with urea addition, the DM loss and the extractive, WSC, and carbon contents were comparable to those without urea addition (Table 2). Addition of urea led to an increased $\mathrm{TN}$ content and a decreased $\mathrm{C} / \mathrm{N}$ ratio. Due to the degradation of urea to ammonia, the $\mathrm{NH}_{3}-\mathrm{N}$ content increased sharply from 0.86 to $1.80 \mathrm{~g} / \mathrm{kg}$ $\mathrm{DM}$ in the first 30 days, which was associated with the increase of $\mathrm{pH}$ from 5.47 to 7.35 . The $\mathrm{NH}_{3}-\mathrm{N}$ content increased slowly (up to $2.04 \mathrm{~g} / \mathrm{kg} \mathrm{DM}$ ) in the following 60 days, while the $\mathrm{pH}$ value decreased to 5.11 indicating further accumulation of acids (Table 2).

As shown in Figure 1, organic acids and ethanol were produced during the ensilage process, while urea addition significantly $(p<0.05)$ changed the profile of lactic acid and propionic acid accumulation. During ensilage of giant reed without urea addition, the contents of lactic acid, 
184 185

acetic acid, propionic acid, and ethanol were in the range of 6.5-10.7, 7.4-19.2, 21.5-35.2, and 8.1-14.0 g/kg DM, respectively (Figure 1). When urea was added, contents of lactic acid and acetic acid were increased to 23.0-36.0 (about 4-fold) and 16.7-21.9 (up to 2-fold) g/kg DM, respectively, while propionic acid content decreased to $3.7-10.1 \mathrm{~g} / \mathrm{kg} \mathrm{DM}$ (2- to 8-fold) (Figure1). Urea addition increased ethanol content to $13.8 \mathrm{~g} / \mathrm{kg}$ DM on day 30 , but resulted in ethanol content on days 60 and 90 comparable $(p>0.05)$ to those without urea addition. Butyric acid was undetectable during the ensilage, except that $3 \mathrm{~g} / \mathrm{kg}$ DM of butyric acid was observed at 90 days of ensilage without urea addition.

The toxicity of organic acids to microorganisms generally depends on the $\mathrm{pH}$ level. At low $\mathrm{pH}$, organic acids are undissociated, and can easily pass through the cell membrane and inhibit growth of microorganisms. At high $\mathrm{pH}$, organic acids are in the form of ionic compounds, which cannot enter the cells by free diffusion alone (Warnecke and Gill, 2005). Therefore, during the ensilage process, higher organic acid contents can be reached at a higher $\mathrm{pH}$ due to the reduced toxicity of organic acids. In addition, $\mathrm{pH}$ levels can also affect the profile of organic acids during ensilage. According to Hofvendahl and Hahn-Hägerdal's study (2000), the optimum pH for lactic acid production by microorganisms ranges between 5.0 and 7.0. As a result, the $\mathrm{pH}$ values (5.1-7.4) during ensilage with urea addition could favor lactic acid production compared to those without urea addition ( $\mathrm{pH} 4.6)$. It should be noted that overloading of urea may cause inhibitory effects on microorganisms due to toxicity of ammonia and increase of $\mathrm{pH}$. An optimal urea loading rate could be determined prior to industrial applications.

Propionic acid accumulation in silage may occur through two mechanisms. One is propionic production by propionic acid bacteria, which is inhibited at a $\mathrm{pH}$ lower than 4.8 (Driehuis et al., 1999); 2) Another one is the degradation of lactic acid to propionic acid by hetero-fermentative 
bacteria, such as Lactobacillus buchneri, with 1,2-propanediol as an intermediate (Driehuis et al., 1999; Elferink et al., 2001). According to literature, the degradation of lactic acid by Lactobacillus buchneri occurred when $\mathrm{pH}$ was about 4.0, but was inhibited at a $\mathrm{pH}$ above 5.8 (Elferink et al., 2001). As shown in Figure 1c and Table 2, propionic acid levels in silage at $\mathrm{pH}$ 4.6 were significantly higher than those at $\mathrm{pH}$ 5.1-7.4. Therefore, the propionic acid accumulation in this study could mainly be attributed to the second mechanism, i.e. lactic acid degradation by hetero-fermentative bacteria, and thus urea addition could reduce the propionic acid generation through increasing $\mathrm{pH}$.

\subsection{Effect of urea addition on lignocellulose degradation in giant reed during ensilage}

Without urea addition, $1.8 \%$ of cellulose, $11.0 \%$ of hemicellulose, and $3.2 \%$ of lignin were degraded in 30 days of ensilage (Figure 2). Degradation of cellulose, hemicellulose, and lignin increased to $3.7 \%, 12.5 \%$, and $6.3 \%$, respectively, during 60 days of ensilage. More cellulose was degraded from day 60 to day 90 , while no significant $(p>0.05)$ increase in hemicellulose and lignin degradation was observed during this period. Urea addition significantly reduced cellulose degradation by at least 2-fold (Figure 2a), but had a minimal effect on hemicellulose degradation (Figure 2b). Besides, urea addition resulted in higher lignin degradation, especially on day 30 and day 90 (Figure 2c).

Since hemicellulose is easier to degrade than cellulose during ensilage (Mcdonal et al., 1991), higher hemicellulose degradation than cellulose degradation has been observed during ensilage of various feedstocks, such as corn stover and orchard grass (Ren et al., 2006; Yahaya et al., 2001). However, the lignin degradation during ensilage varied dramatically depending on the feedstock. For example, lignin degradation of 3-4\% was observed during 4-month ensilage of hemp, but not for ensilage of maize or fava beans (Pakarinen et al., 2011). Improved lignin 
230 degradation by urea addition was also observed during the ensilage of hemp (Pakarinen et al., $2312011)$.

\section{3.3. Effect of urea addition on enzymatic digestibility of ensiled giant reed}

233 Neither ensilage nor the urea addition significantly enhanced enzymatic digestibility of giant 234 reed $(p>0.05)$ (Figure 3). Improved enzymatic digestibility (35-42\% increase) during the ensilage 235 process has been reported in studies of sugar beet, rye, and clover (Oleskowicz-Popiel et al., 236 2011; Zheng et al., 2011). However, Oleskowicz-Popiel et al. (2011) reported that no 237 improvement of enzymatic convertibility was observed during ensilage of maize. Pakarinen et al. 238 (2011) suggested that ensilage can lead to decreased enzymatic hydrolysis yield of corn, as 239 highly digestible carbohydrates have been converted into acids during the ensilage process. In 240 addition, Walton et al. (2010) mentioned that organic acids generated during ensilage may 241 interfere with enzymatic hydrolysis. Therefore, ensilage may not necessarily improve the 242 enzymatic digestibility of feedstocks.

243 Pakarinen et al. (2011) reported that hemp preserved with $3 \%$ urea achieved a carbohydrate 244 increase of $46 \%$ in enzymatic hydrolysis compared to the fresh material. The urea dosage $(2 \%)$ 245 used in this study might be not enough to obtain a significant enhancement in enzymatic 246 digestibility of giant reed. Besides, the effect of urea addition on enzymatic digestibility of 247 ensiled biomass could also vary for different feedstocks.

\section{3.4. Effect of urea addition on methane production via anaerobic digestion}

249 Daily methane yield and methane content during 30-day AD of fresh giant reed and 90-day 250 ensiled giant reed are presented in Figure 4. The daily methane yields all peaked in about 2-4 251 days, while ensiled giant reed (90-day ensilage) showed higher peak daily methane yields than 252 fresh giant reed (0-day ensilage). The peak daily methane yields of giant reed ensiled with and 
253 without urea addition (18.6 and $17.7 \mathrm{~L} / \mathrm{kg} \mathrm{VS})$ were $16 \%$ and $10 \%$ higher than those of fresh 254 giant reed, respectively (Figure 4a). This is likely attributed to the presence of organic acids in 255 the ensiled biomass, which expedites methane production. After the initiation of AD, methane 256 contents increased quickly reaching 64.1-69.5\% in 4 days, and then maintained at these levels 257 with minimal fluctuations until the end of the AD (Figure 4b). Besides, removal efficiencies of 258 organic matter during all the AD tests were $18-21 \%$.

$259 \quad \mathrm{AD}$ of fresh giant reed with and without urea addition obtained similar cumulative methane 260 yields of about $147.3 \mathrm{~L} / \mathrm{kg}$ VS (Figure 5), which was close to the methane yield (150.8 L/kg VS) 261 obtained by L-AD of giant reed in a previous study (Yang and Li, 2014). As shown in Figure 5, 262 the cumulative methane yield was generally improved by ensilage, and longer ensilage time 263 resulted in higher methane yields. Besides, 60-day and 90-day ensilage with urea addition 264 achieved significant $(p<0.05)$ improvements in the cumulative methane yield compared to those 265 of fresh giant reed. Specifically, with urea addition, 60-day and 90-day ensilage increased the 266 cumulative methane yields to 171 and $173 \mathrm{~L} / \mathrm{kg}$ VS, respectively, which were $16 \%$ and $18 \%$ 267 higher than those of fresh giant reed. Similarly, Pakarines et al. (2008) reported that ensilage 268 increased the methane yield of different grasses (ryegrass and mixture of timothy, red clover and 269 meadow fescue) by up to $19 \%$.

270 The improved methane yields by $\mathrm{AD}$ of ensiled giant reed could be attributed to the 271 production of organic compounds, especially lactic acid, acetic acid and ethanol, during ensilage, 272 because these organic compounds can be readily utilized by microorganisms in AD systems for 273 biogas production. Weak correlations $\left(R^{2}<0.04\right)$ were obtained between cumulative methane 274 yield and propionic acid or butyric acid, which indicated that these acids may not have 275 contributed to the improved methane yield. In contrast, strong linear relationships were found 
276 between cumulative methane yield and lactic acid $\left(R^{2}=0.85\right)$ (Figure 6a) or acetic acid $\left(R^{2}=\right.$ 277 0.91) (Figure 6b) or ethanol $\left(R^{2}=0.78\right)$ (Figure 6c). A stronger linear relationship was observed 278 between cumulative methane yield and a combination of lactic acid, acetic acid and ethanol $\left(R^{2}=\right.$ 279 0.96) (Figure 6d). This result supports the above mentioned hypothesis that methane yield of 280 giant reed can be improved by ensilage, especially with urea addition, due to production of 281 organic acids and ethanol during ensilage.

282

\section{Conclusions}

Ensilage with or without urea addition was found to be a stable method for storage of giant reed with minimal dry matter loss. Urea addition enhanced production of lactic acid and acetic acid production, while it reduced propionic acid production during ensilage of giant reed. Urea

287 addition resulted in reduced cellulose and hemicellulose degradation, and improved lignin 288 degradation in giant reed during ensilage. Although ensilage didn't significantly increase the 289 enzymatic digestibility of giant reed, methane yield during AD of giant read was still improved by the ensilage process probably due to the production of lactic acid, acetic acid and ethanol.

\section{Acknowledgement}

This project was funded by the USDA NIFA Biomass Research and Development Initiative 294 Program (Award No. 2012-10008-20302). The authors would like to thank Mrs. Mary Wicks 295 (Department of Food, Agricultural and Biological Engineering, OSU) for reading through the manuscript and providing useful suggestions. 


\section{References}

1. Adney, B., Baker, J., 2008. Measurement of cellulase activities. National Renewable Energy Laboratory Technical Report NREL/TP-510-42628.

2. APHA, 2005. Standard Methods for the Examination of Water and Wastewater. American Public Health Association, Washington, D.C.

3. Corno, L., Pilu, R., Adani, F., 2014. Arundo donax L.: A non-food crop for bioenergy and biocompound production. Biotechnol. Adv. 32, 1535-1549.

4. Darr, M.J., Shah, A., 2012. Biomass storage: an update on industrial solutions for baled biomass feedstocks. Biofuels 3, 321-332.

5. Di Girolamo, G., Grigatti, M., Barbanti, L., Angelidaki, I., 2013. Effects of hydrothermal pretreatments on Giant reed (Arundo donax) methane yield. Bioresour. Technol. 147, 152-159.

6. Dias-da-Silva, A., SundstØl, F., 1986. Urea as a source of ammonia for improving the nutritive value of wheat straw. Anim. Feed Sci. Technol. 14, 67-79.

7. Dragoni, F., Ragaglini, G., Di Nasso, N., Tozzini, C., Bonari, E., Booth, E., Halford, N., Shield, I. et al., 2011. Suitability of giant reed and miscanthus for biogas: preliminary investigations on harvest time and ensiling. Aspect. Appl. Biol. 112, 291-296.

8. Driehuis, F., Elferink, S.J.W.H., Spoelstra, S.F., 1999. Anaerobic lactic acid degradation during ensilage of whole crop maize inoculated with Lactobacillus buchneri inhibits yeast growth and improves aerobic stability. J. Appl. Microbiol. 87, 583-594.

9. Elferink, S.J.O., Krooneman, J., Gottschal, J.C., Spoelstra, S.F., Faber, F., Driehuis, F., 2001. Anaerobic conversion of lactic acid to acetic acid and 1, 2-propanediol by Lactobacillus buchneri. Appl. Environ. Microbiol. 67, 125-132. 
321 10. Guedes, C.M., Rodrigues, M.M., Gomes, M.J., Silva, S.R., Ferreira, L.M., Mascarenhas-

322 Ferreira, A., 2006. Urea treatment of whole crop triticale at four growth stages: effects on

323 chemical composition and on in vitro digestibility of cell wall. J. Sci. Food Agric. 86, 964-970.

324 11. Hattingh, W.H.J., Thiel, P.G., Siebert, M.L., 1967. Determination of protein content of 325 anaerobic digesting sludge. Water Res. 1, 185-189.

326 12. Herrmann, C., Heiermann, M., Idler, C., 2011. Effects of ensiling, silage additives and 327 storage period on methane formation of biogas crops. Bioresour. Technol. 102, 5153-5161.

328 13. Hofvendahl, K., Hahn-Hägerdal, B., 2000. Factors affecting the fermentative lactic acid 329 production from renewable resources. Enzyme Microb. Technol. 26, 87-107.

330 14. Ibrahim, M.N.M., Wijeratne, A.M.U., Costa, M.J.I., 1985. Effect of different sources of 331 urease on the treatment time and digestibility of urea-ammonia treated rice straw. Agr. Wastes $33213,197-205$.

333 15. Mascarenhas-Ferreira, A., Guedes, C.V., Dias-da-Silva, A.A., 1989. Effects of urea treatment 334 on chemical composition and in vitro digestibility of meadow hays of Northern Portugal. 335 Anim. Feed Sci. Technol. 25, 157-167.

336 16. Mcdonal, P., Henderson, A.R., Heron, S.J.E., 1991. The Biochemistry of Silage. Chalcombe 337 Publications, Marlow, Bucks, UK.

338 17. Neureiter, M., dos Santos, J.T.P., Lopez, C.P., Pichler, H., Kirchmayr, R., Braun, R., 2005. 339 Effect of silage preparation on methane yields from whole crop maize silages. In Proceedings 340 of the 4th International Symposium on Anaerobic Digestion of Solid Waste: 31 August-2 341 September 2005; Water Sci Techn. Volume 53., p 109-115

342 18. Oleskowicz-Popiel, P., Thomsen, A.B., Schmidt, J.E., 2011. Ensiling-Wet-storage method 343 for lignocellulosic biomass for bioethanol production. Biomass Bioenergy 35, 2087-2092. 
344 19. Pakarinen, A., Maijala, P., Jaakkola, S., Stoddard, F.L., Kymäläinen, M., Viikari, L., 2011.

345 Evaluation of preservation methods for improving biogas production and enzymatic 346 conversion yields of annual crops. Biotechnol. Biofuels 4, 1-13.

347 20. Pakarinen, O., Lehtomäki, A., Rissanen, S., Rintala, J., 2008. Storing energy crops for 348 methane production: effects of solids content and biological additive. Bioresour. Technol. 99, $349 \quad 7074-7082$.

350 21. Ragaglini, G., Dragoni, F., Simone, M., Bonari, E., 2014. Suitability of giant reed (Arundo 351 donax L.) for anaerobic digestion: Effect of harvest time and frequency on the biomethane 352 yield potential. Bioresour. Technol. 152, 107-115.

353 22. Ren, H., Richard, T.L., Chen, Z., Kuo, M., Bian, Y., Moore, K.J., Patrick, P., 2006. Ensiling 354 corn stover: effect of feedstock preservation on particleboard performance. Biotechnol. Prog. $355 \quad 22,78-85$.

356 23. Rossa, B., Tüffers, A.V., Naidoo, G., Willert, D.J., 1998. Arundo donax L.(Poaceae)-a C3 357 species with unusually high photosynthetic capacity. Bot. Acta 111, 216-221.

358 24. Sarwar, M., Khan, M.A., 2004. Effect of organic acids or fermentable carbohydrates on 359 digestibility and nitrogen utilisation of urea-treated wheat straw in buffalo bulls. Crop Pasture $360 \quad$ Sci. 55, 223-228.

361 25. Scordia, D., Cosentino, S.L., Jeffries, T.W., 2013. Enzymatic hydrolysis, simultaneous 362 saccharification and ethanol fermentation of oxalic acid pretreated giant reed (Arundo donax 363 L.). Ind. Crops. Prod. 49, 392-399.

364 26. Selig, M., Weiss, N., Ji, Y., 2008. Enzymatic saccharification of lignocellulosic biomass. 365 National Renewable Energy Laboratory Technical Report NREL/TP-510-42629. 
27. Sluiter, A., Hames, B., Ruiz, R., Scarlata, C., Sluiter, J., Templeton, D., Crocker, D., 2008. Determination of structural carbohydrates and lignin in biomass. National Renewable Energy Laboratory Technical Report NREL/TP-510-42618.

28. Vervaeren, H., Hostyn, K., Ghekiere, G., Willems, B., 2010. Biological ensilage additives as pretreatment for maize to increase the biogas production. Renew. Energ. 35, 2089-2093.

29. Walton, S., van Heiningen, A., van Walsum, P., 2010. Inhibition effects on fermentation of hardwood extracted hemicelluloses by acetic acid and sodium. Bioresour. Technol. 101, 19351940.

30. Warnecke, T., Gill, R.T., 2005. Organic acid toxicity, tolerance, and production in Escherichia coli biorefining applications. Microb. Cell Fact. 4, 25.

31. Yahaya, M.S., Kimura, A., Harai, J., Nguyen, H.V., Kawai, M., Takahashi, J., Matsuoka, S., 2001. Effect of length of ensiling on silo degradation and digestibility of structural carbohydrates of lucerne and orchardgrass. Anim. Feed Sci. Technol. 92, 141-148.

32. Yang, L., Li, Y., 2014. Anaerobic digestion of giant reed for methane production. Bioresour. Technol. 171, 233-239.

33. Yu, Z., Schanbacher, F.L., 2010. Production of Methane Biogas as Fuel Through Anaerobic Digestion, in: Singh, O.V., Harvey, S.P. (Eds.), Sustainable Biotechnology. Springer Netherlands, pp. 105-127.

34. Zeng, M., Mosier, N.S., Huang, C.P., Sherman, D.M., Ladisch, M.R., 2007. Microscopic examination of changes of plant cell structure in corn stover due to hot water pretreatment and enzymatic hydrolysis. Biotechnol. Bioeng. 97, 265-278. 
387 35. Zheng, Y., Yu, C., Cheng, Y.S., Zhang, R., Jenkins, B., VanderGheynst, J.S., 2011. Effects 388 of ensilage on storage and enzymatic degradability of sugar beet pulp. Bioresour. Technol. 102, 389 1489-1495.

390

391

392 
Table 1. Characteristics of giant reed biomass and inoculum for AD

\begin{tabular}{lcc}
\hline Parameters & Giant reed & Inoculum for AD \\
\hline DM, \% & $43.53 \pm 0.55$ & $6.71 \pm 0.01$ \\
ODM, \%DM & $92.19 \pm 0.10$ & $63.85 \pm 0.05$ \\
TN, \% DM & $0.77 \pm 0.03$ & $3.83 \pm 0.07$ \\
TC, \% DM & $49.98 \pm 0.03$ & $39.06 \pm 0.52$ \\
C/N & $64.55 \pm 2.47$ & $10.20 \pm 0.06$ \\
pH & $5.57 \pm 0.03$ & $7.99 \pm 0.01$ \\
Extractives, \%DM & $21.80 \pm 0.76$ & $14.13 \pm 0.91$ \\
$\quad$ WSC, \%DM & $4.94 \pm 0.25$ & $0.46 \pm 0.08$ \\
$\quad$ Cellobiose, \%DM & $1.70 \pm 0.08$ & $\mathrm{ND}$ \\
$\quad$ Glucose, \%DM & $1.47 \pm 0.01$ & $\mathrm{ND}$ \\
Cellulose, \%DM & $27.73 \pm 0.17$ & $1.11 \pm 0.05$ \\
Hemicellulose, \%DM & $15.65 \pm 0.29$ & $\mathrm{ND}$ \\
Lignin, \%DM & $16.66 \pm 0.38$ & $\mathrm{NA}$ \\
Crude protein, \%DM & $4.06 \pm 0.66$ & $\mathrm{ND}$ \\
NH ${ }_{3}-\mathrm{N}, \%$ DM & $0.06 \pm 0.02$ & $5.25 \pm 0.52$ \\
Ash, \%DM & $7.81 \pm 0.09$ & $36.15 \pm 0.05$ \\
\hline
\end{tabular}


Table 2. Dry matter (DM) loss, water soluble carbohydrates (WSC), extractives, ammonia nitrogen ( $\left.\mathrm{NH}_{3}-\mathrm{N}\right)$, total nitrogen (TN) and total carbon (TC) content; carbon to nitrogen $(\mathrm{C} / \mathrm{N})$ ratio; and $\mathrm{pH}$ during 90-day ensilage of giant reed with and without urea addition.

\begin{tabular}{|c|c|c|c|c|c|c|c|c|}
\hline $\begin{array}{l}\text { Time } \\
\text { (day) }\end{array}$ & $\begin{array}{l}\text { DM loss } \\
(\%)\end{array}$ & $\begin{array}{c}\text { WSC } \\
(\% \text { DM) }\end{array}$ & $\begin{array}{c}\text { Extractives } \\
(\% \text { DM) }\end{array}$ & $\begin{array}{c}\mathrm{NH}_{3}-\mathrm{N} \\
(\mathrm{g} / \mathrm{kg} \mathrm{DM})\end{array}$ & $\begin{array}{c}\text { TN } \\
(\% \text { DM) }\end{array}$ & $\begin{array}{c}\text { TC } \\
(\% \text { DM) }\end{array}$ & $\mathbf{C} / \mathbf{N}$ & pH \\
\hline \multicolumn{9}{|c|}{ 0\% urea } \\
\hline 0 & $0.00 \pm 0.00 c$ & $4.94 \pm 0.25 a$ & $21.81 \pm 0.69 a$ & $0.42 \pm 0.06 c$ & $0.67 \pm 0.01 d$ & $45.12 \pm 0.04 c$ & $67.53 \pm 1.02 b$ & $5.40 \pm 0.03 \mathrm{bcd}$ \\
\hline 30 & $0.98 \pm 0.02 b$ & $0.36 \pm 0.02 b$ & $14.98 \pm 0.51 b$ & $0.39 \pm 0.02 c$ & $0.62 \pm 0.03 d$ & $46.32 \pm 0.53 \mathrm{ab}$ & $74.82 \pm 3.25 \mathrm{a}$ & $4.60 \pm 0.08 \mathrm{de}$ \\
\hline 60 & $1.14 \pm 0.14 \mathrm{ab}$ & $0.22 \pm 0.09 b$ & $15.16 \pm 0.11 b$ & $0.36 \pm 0.08 c$ & $0.63 \pm 0.02 \mathrm{~d}$ & $45.79 \pm 0.53 \mathrm{ab}$ & $72.66 \pm 2.97 a$ & $4.56 \pm 0.07 e$ \\
\hline 90 & $1.20 \pm 0.22 \mathrm{a}$ & $0.40 \pm 0.04 b$ & $15.26 \pm 0.86 b$ & $0.39 \pm 0.03 c$ & $0.64 \pm 0.05 d$ & $46.17 \pm 0.21 \mathrm{a}$ & $72.43 \pm 5.84 a b$ & $4.56 \pm 0.06 \mathrm{e}$ \\
\hline \multicolumn{9}{|c|}{$2 \%$ urea } \\
\hline 0 & $0.00 \pm 0.00 c$ & $4.94 \pm 0.25 a$ & $21.81 \pm 0.69 a$ & $0.86 \pm 0.01 b$ & $1.42 \pm 0.01 \mathrm{a}$ & $45.26 \pm 0.08 b c$ & $31.95 \pm 0.31 \mathrm{e}$ & $5.47 \pm 0.12 b c$ \\
\hline 30 & $0.87 \pm 0.10 b$ & $0.23 \pm 0.01 b$ & $15.61 \pm 0.09 b$ & $1.80 \pm 0.09 a$ & $0.82 \pm 0.02 c$ & $46.09 \pm 0.27 \mathrm{ab}$ & $56.26 \pm 0.95 c$ & $7.35 \pm 0.15 a$ \\
\hline 60 & $0.91 \pm 0.11 b$ & $0.20 \pm 0.03 b$ & $15.89 \pm 0.46 b$ & $1.95 \pm 0.13 a$ & $1.14 \pm 0.04 b$ & $45.99 \pm 0.42 \mathrm{ab}$ & $40.37 \pm 1.84 d$ & $6.20 \pm 0.63 b$ \\
\hline 90 & $0.97 \pm 0.15 b$ & $0.26 \pm 0.04 b$ & $15.67 \pm 0.27 b$ & $2.04 \pm 0.19 a$ & $1.12 \pm 0.01 b$ & $46.05 \pm 0.29 a b c$ & $41.25 \pm 0.56 \mathrm{~d}$ & $5.11 \pm 0.47 \mathrm{cde}$ \\
\hline
\end{tabular}

Within columns, means that are not sharing a letter are significantly different at $p<0.05$. 
Figures

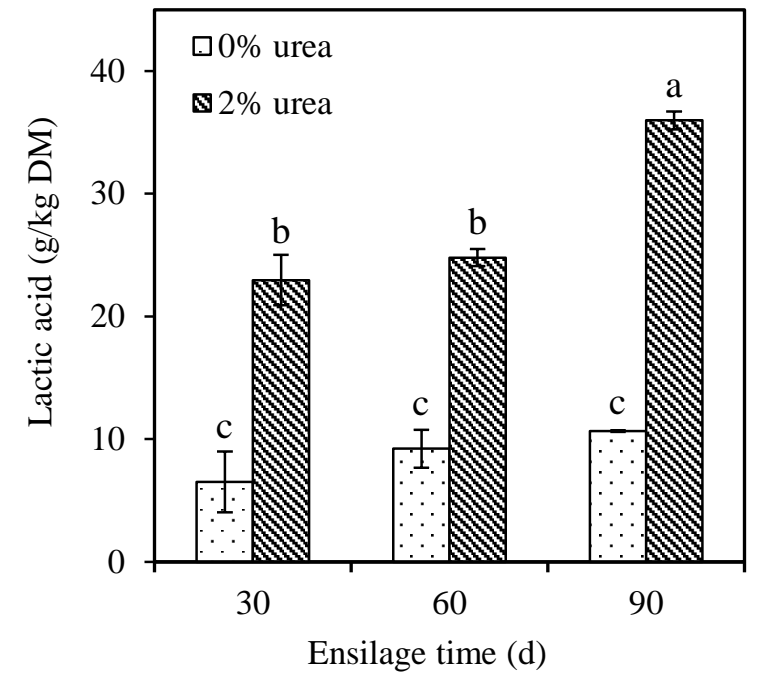

(a)

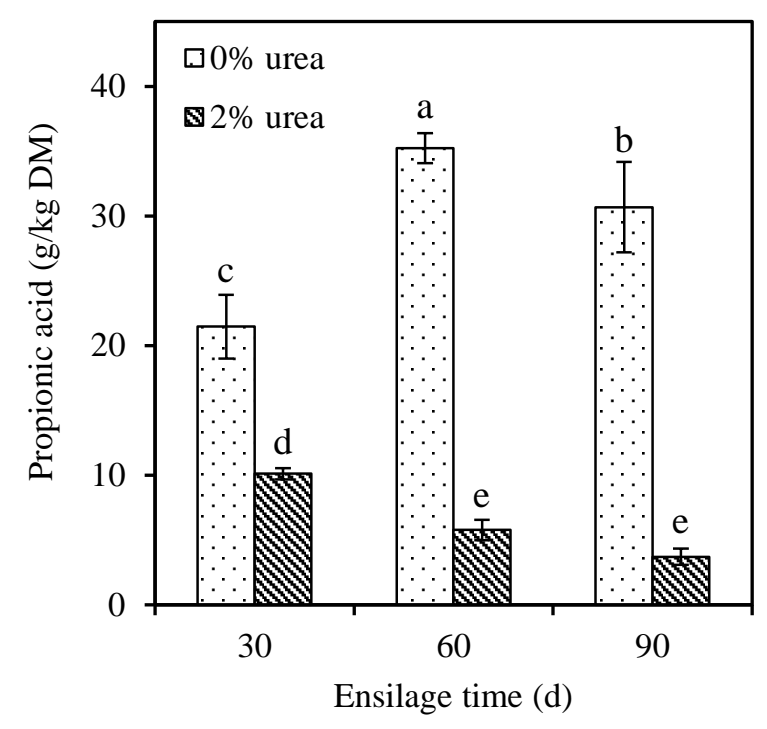

(c)

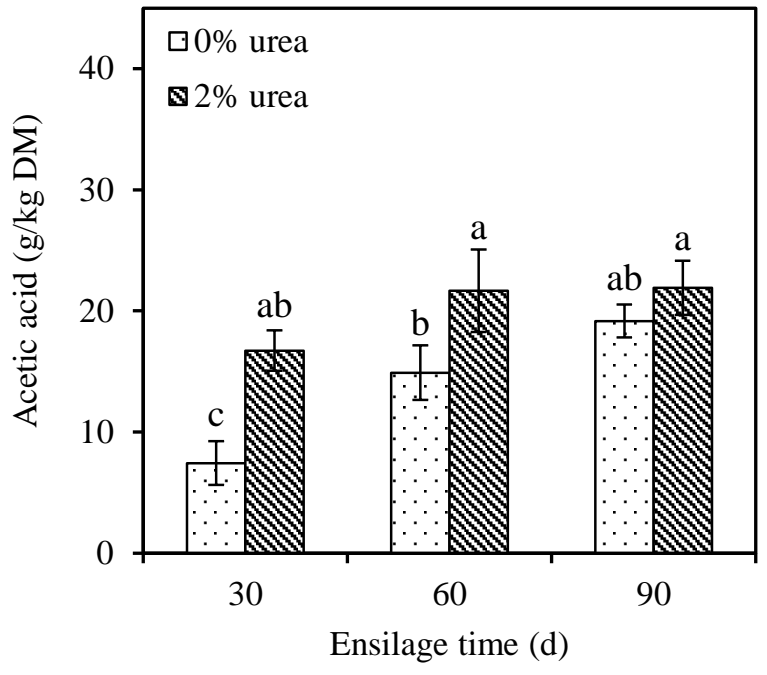

(b)

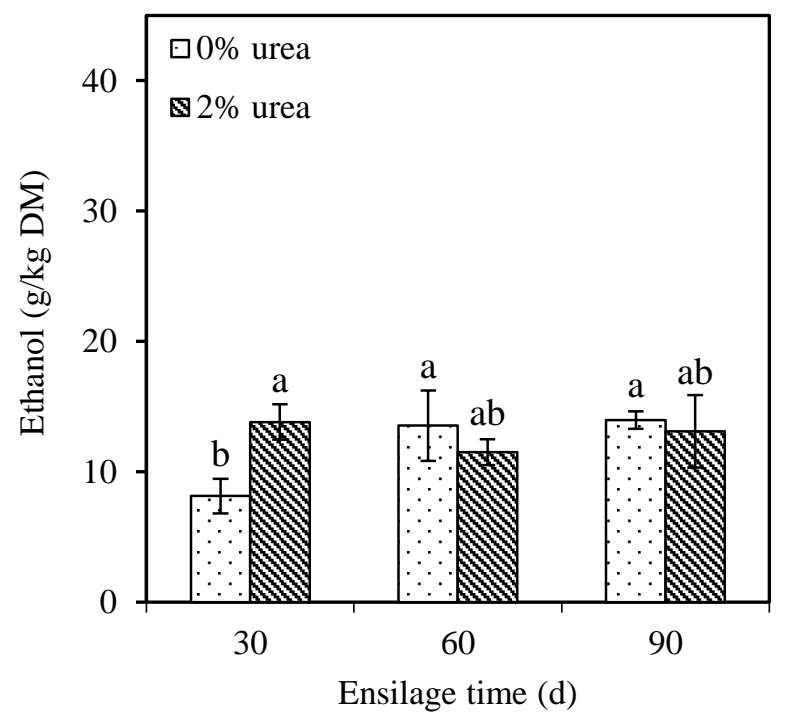

(d)

Figure 1. Effect of urea addition on organic acid and ethanol production during giant reed ensilage for different periods of time

In each figure, means that are not sharing a letter are significantly different at $p<0.05$. 


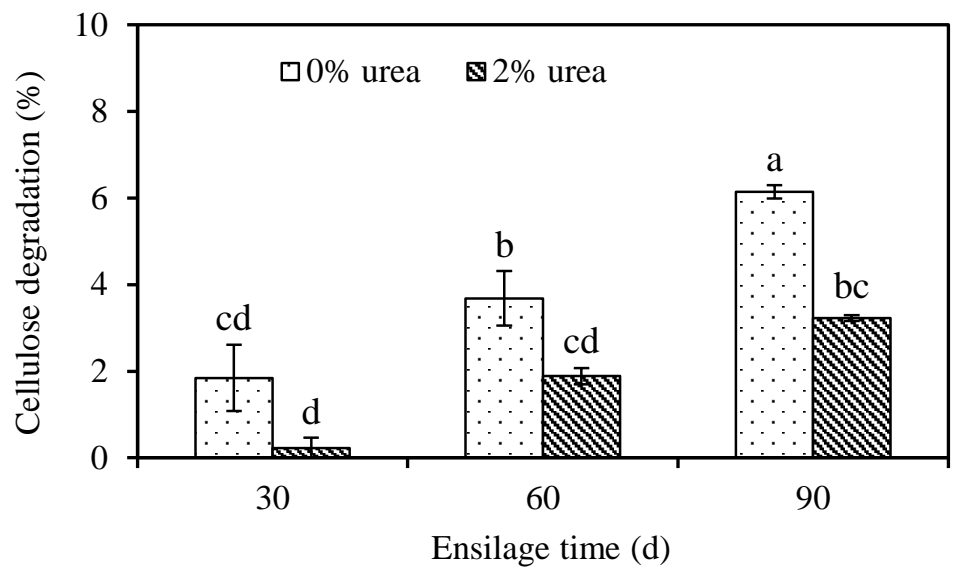

(a)

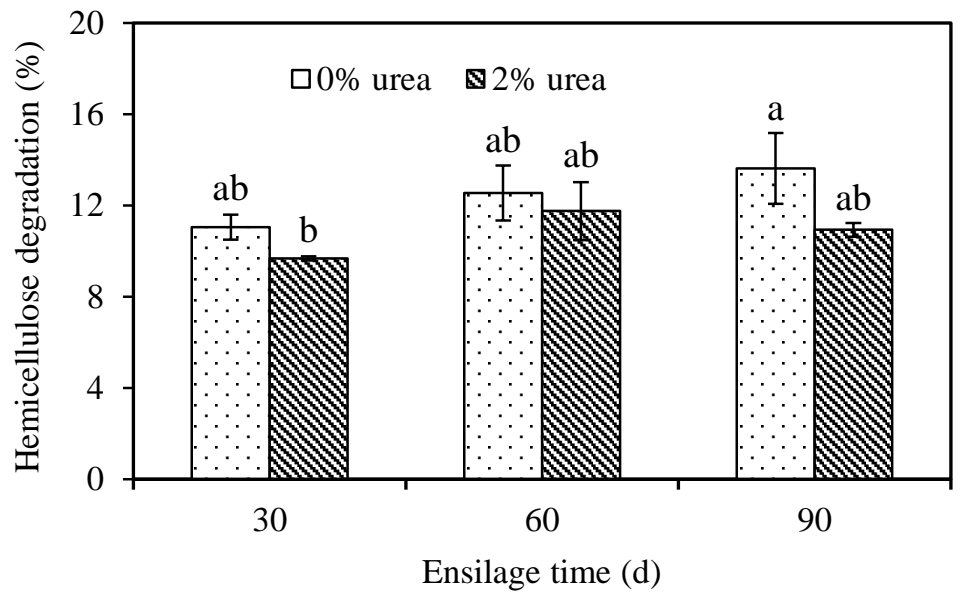

(b)

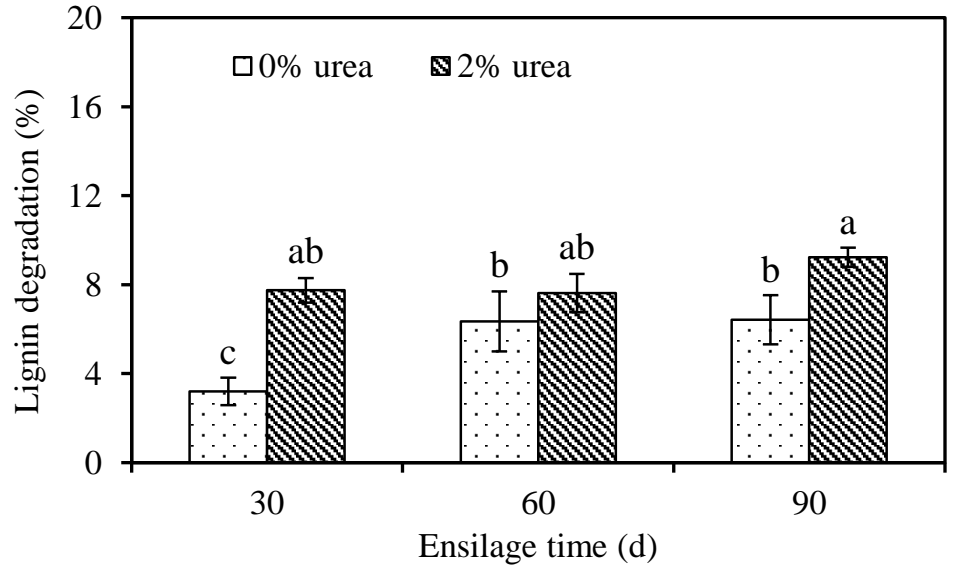

(c)

Figure 2. Effect of urea addition on degradation of cellulose (a), hemicellulose (b), and lignin (c) in giant reed during ensilage for different periods of time

In each figure, means that are not sharing a letter are significantly different at $p<0.05$. 


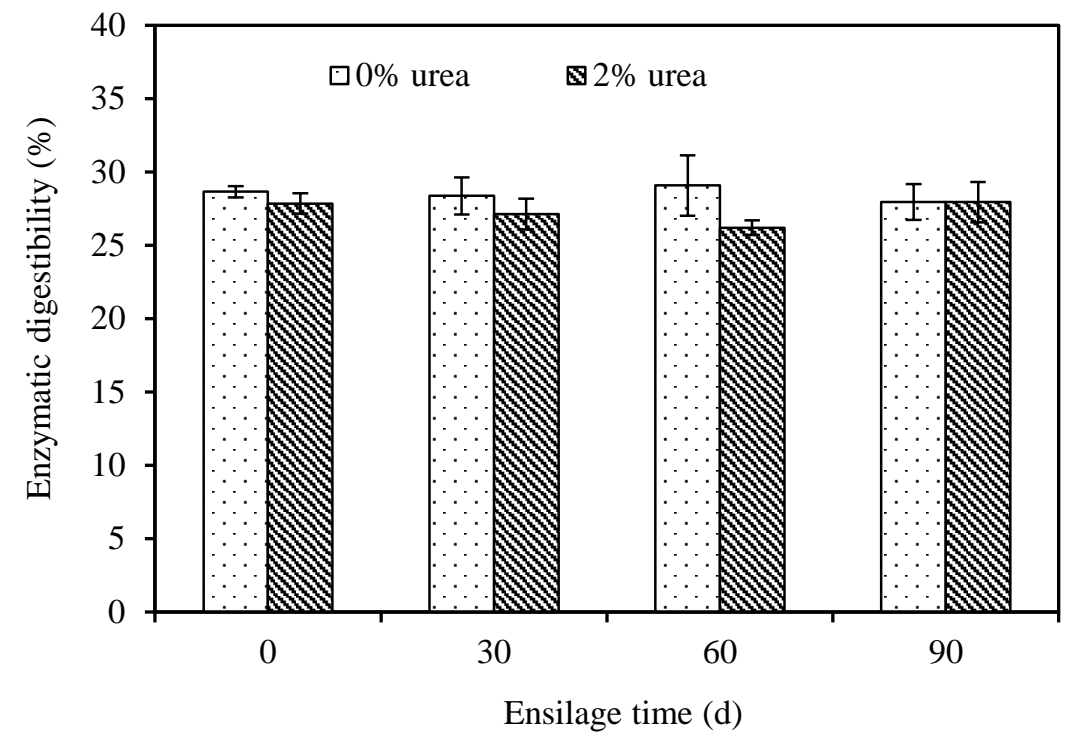

Figure 3. Effect of urea addition and ensilage time on enzymatic digestibility of giant reed 


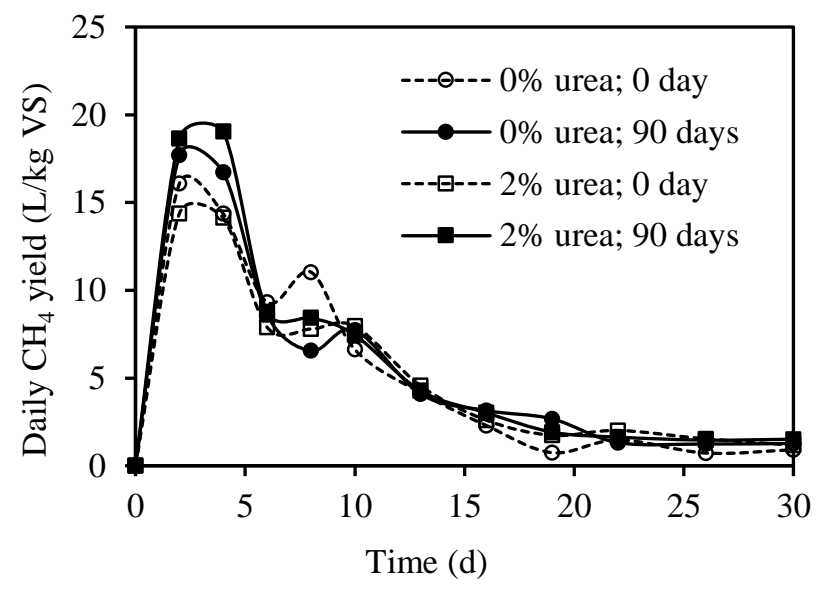

(a)

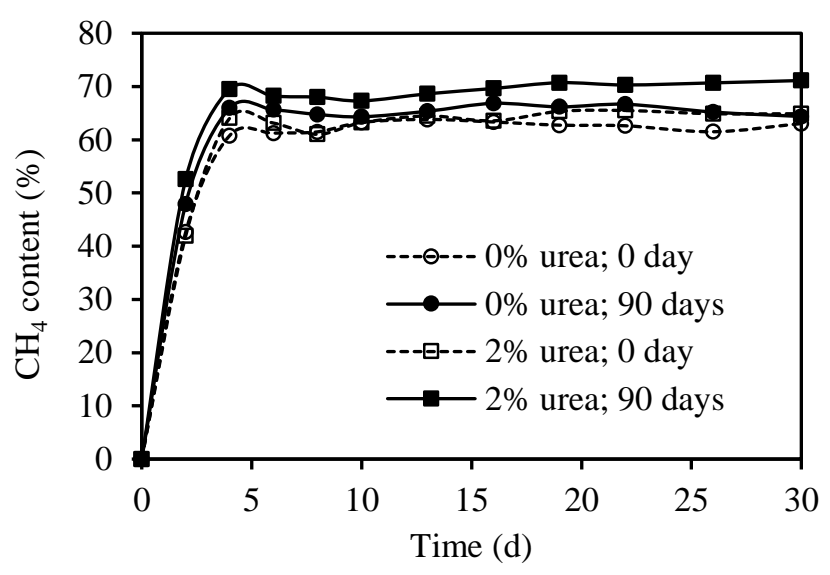

(b)

Figure 4. Effect of urea addition and ensilage on the daily methane yield (a) and methane content (b) of giant reed during 30-day AD 


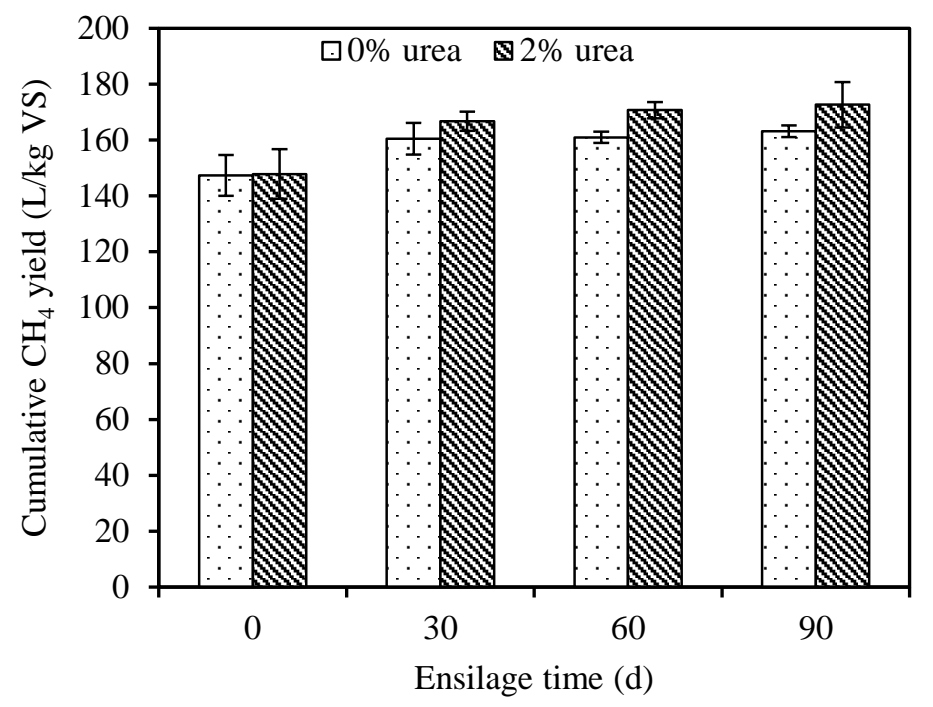

Figure 5. Effect of urea addition and ensilage time on cumulative methane yield of giant reed during 30-day AD 

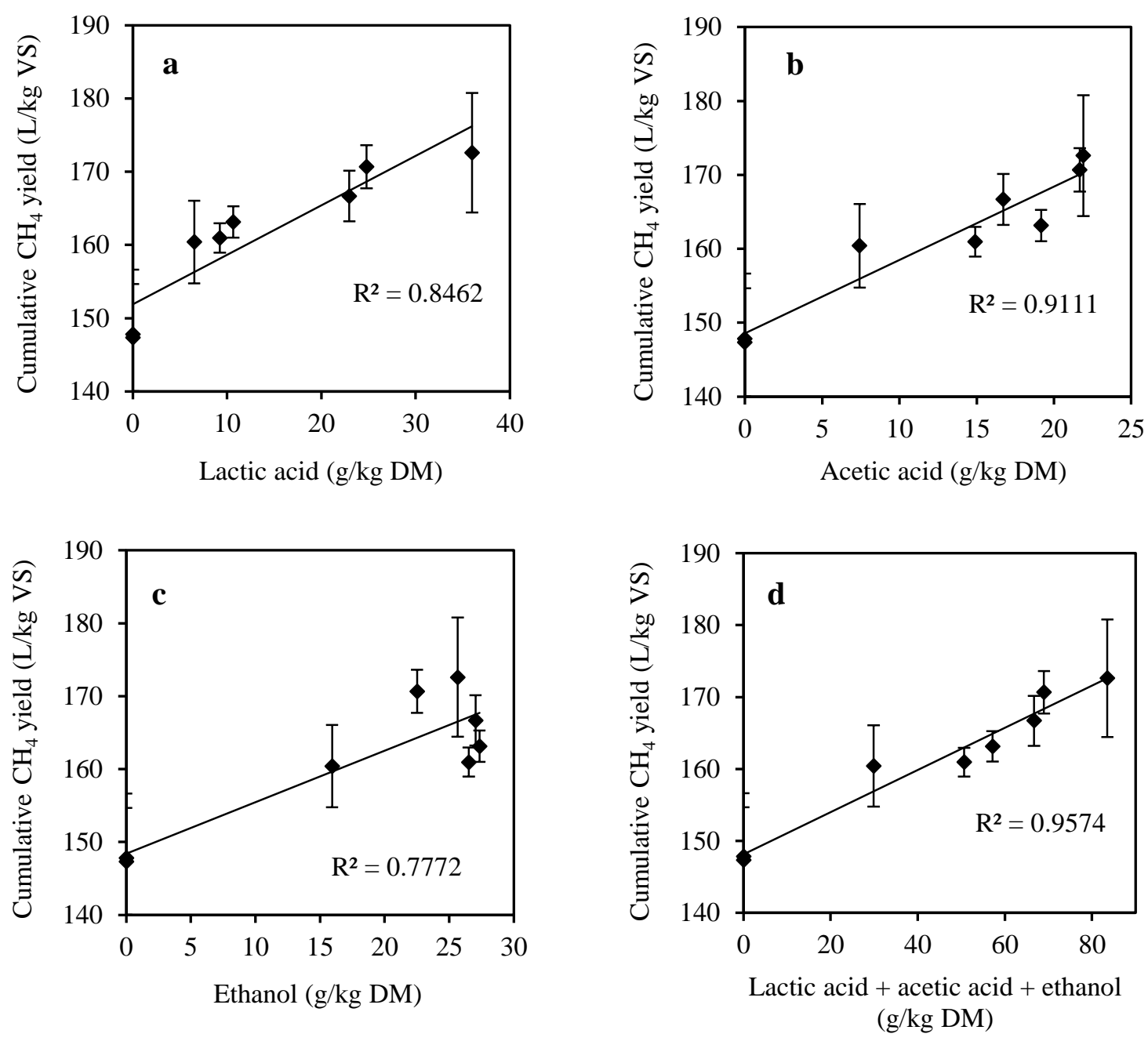

Figure 6. Correlation between cumulative methane yield and contents of organic acids and ethanol in the feedstock of $\mathrm{AD}$

(Lactic acid and ethanol content have been converted into acetic acid equivalent values based on their theoretical methane yields, i.e. 373,373 and $730 \mathrm{~L} / \mathrm{kg}$ for lactic acid, acetic acid and ethanol, respectively) 